\title{
Contracaecum ovale (Nematoda: Anisakidae) from Rollandia rolland Quoy \& Gaimard 1824 (Aves, Podicipedidae) in Argentina
}

\author{
Contracaecum ovale (Nematoda: Anisakidae) de Rollandia rolland Quoy \& Gaimard \\ 1824 (Aves, Podicipedidae) na Argentina \\ Noelia Adelina Galeano ${ }^{1}$; Ruben Daniel Tanzola ${ }^{1 *}$
}

\begin{abstract}
${ }^{1}$ Laboratorio de Patología de Organismos Acuáticos, Departamento de Biología, Bioquímica y Farmacia, Universidad Nacional del Sur - UNS, Bahía Blanca, Argentina
\end{abstract}

Received April 1, 2011

Accepted May 29, 2011

\begin{abstract}
Necropsy on 15 specimens of white-tufted grebe, Rollandia rolland, caught in the Mar Chiquita and Chascomús lagoons (Buenos Aires province), revealed the presence of Contracaecum ovale (Linstow, 1907). This nematode shows a marked specificity for podicipediform birds. The specimens were identified from morphological study on features such as cephalic and esophageal structures and caudal papillae, using both optical and scanning electron microscopy. This is the first record of C. ovale parasitizing $R$. rolland in Argentina.
\end{abstract}

Keywords: Contracaecum ovale, Nematoda, Rollandia rolland, Podicipedidae.

\section{Resumo}

Necropsia de 15 espécimes de mergulhão-de-orelha-branca, Rollandia rolland, coletados nas lagoas Mar Chiquita e Chascomús (Província de Buenos Aires), revelou a presença de Contracaecum ovale (Linstow, 1907). Esse nematóide tem uma marcada especificidade pelas aves podicipediformes. Os espécimes foram identificados a partir de características, tais como estruturas morfológicas cefálicas e esofágicas e papilas caudais, utilizando-se microscopia óptica e microscopia eletrônica de varredura (MEV). Esse é o primeiro registro de C. ovale parasito de R. rolland na Argentina.

Palavras-chave: Contracaecum ovale, Nematoda, Rollandia rolland, Podicipedidae.

Contracaecum ovale (Linstow, 1907) is an ascaridoid nematode with pronounced specificity for podicipediform hosts. It was first described in Podiceps cristatus from Germany. Cram (1927) described this species in the same host and Baylis (1939) included it in a list of the parasites of British birds. Subsequently, Mozgovoi (1953) described it briefly in P. cristatus from Russia. Vuylsteke (1953) recorded C. ovale in P. ruficollis capensis from the Congo. Macko (1961) described it in P. griseigena and $P$. nigricollis from the Czech Republic. The only previous record from the Neotropical region is that of Hartwich (1964) in Podilymbus podiceps in Brazil. Stock and Holmes (1987) cited C. ovale as a member of the parasite communities of $P$. grisegena, $P$. nigricollis and $P$. auritus in Canada. To the best of our knowledge, some details of the external morphology of this species remain unknown.

\footnotetext{
*Corresponding author: Ruben Tanzola

Laboratorio de Patología de Organismos Acuáticos, Departamento de Biología, Bioquímica y Farmacia, Universidad Nacional del Sur,

San Juan, 670, CP 8000, Bahía Blanca, Buenos Aires, Argentina

e-mail: rtanzola@uns.edu.ar
}

This note reports C. ovale in the white-tufted grebe, Rollandia rolland, for the first time in Argentina. White-tufted grebes are the most common grebe in lakes and lagoons throughout Argentina, from Misiones to Tierra del Fuego (STORER, 1967; FJELDSA, 2004). In this paper, C. ovale is described using optical microscopy and scanning electron microscopy (SEM).

The helminth specimens, which belong to the author's personal collection, were obtained between 1983 and 1985 from 15 individuals of $R$. rolland (Aves: Podicipediformes) that were killed using a shotgun (with permission for scientific hunting granted by the Fauna Directorate, Ministry of Agrarian Affairs, Government of the Province of Buenos Aires) in the Mar Chiquita lagoon $(\mathrm{n}=12)\left(37^{\circ} 46^{\prime} \mathrm{S}\right.$ and $\left.57^{\circ} 27^{\prime} \mathrm{W}\right)$ and Chascomús lagoon $(\mathrm{n}=3)\left(35^{\circ} 40^{\prime} \mathrm{S}\right.$ and $\left.58^{\circ} 00^{\prime} \mathrm{W}\right)$ in Buenos Aires province. Once in the laboratory, the birds were dissected and nematodes were collected from the stomach and fixed and stored in 5\% formalin. Some specimens were cleared in lactophenol and examined by means of optical microscopy. Drawings were made with the aid of a camera lucida. Measurements, in millimeters, were expressed as 
the mean followed by the range in parentheses. Other specimens, fixed in 5\% formalin were dehydrated in acetone, dried using the $\mathrm{CO}_{2}$ critical point method and observed and photographed using scanning electron microscopy (SEM) (Evoup/LEO). The spatial location of the male's papillae was described in accordance with Fagerholm (1991). The voucher specimen was deposited in the Helminthological collection of the Museo de la Plata, Argentina (no MLP 6313). The measurements made in this study and those given by previous authors are presented in Table 1. Morphological details are shown in Figures 1-8.

The entire body of $C$. ovale is transversally striated (Figure 2). The lips are mostly oval in shape with two small auricles (Figure 3). There are two large double papillae on the dorsal lip and one on each ventrolateral lip (Figure 3) and, additionally, an amphid is present on each ventrolateral lip. The interlabia were triangular in shape and shorter than the lips (Figure 3). The deirids were inconspicuous and button-shaped (Figure 4)

Measurements on male specimens $(\mathrm{n}=3)$ : body length 18.5 (18-19); maximum body width 0.69 (0.67-0.72); distance from anterior end to nerve ring and deirids 0.09 (0.08-0.1) and 0.69 , respectively; esophagus length $(\mathrm{n}=1) 3.4$; intestinal caecum length $(n=1) 2.7$; ventriculus length $(n=1) 0.16$; ventricular appendix length $(n=1) 0.70$; spicules of equal length, reaching almost half of the body; spicule length $(\mathrm{n}=1)$ 2.87; and tail length 0.20 (0.17-0.23). The caudal extremity was conical, bearing 12-16 pairs of precloacal papillae. The precloacal transverse stria ("pt") zone included three pairs of precloacal papillae (Figure 5). There was one double paracloacal papilla (sensu FAGERHOLM, 1991) and five pairs of single postcloacal papillae: two subventral pairs, two sublateral pairs ("laterodorsal" sensu HARTWICH, 1964) and one pair of phasmids at the end (Figure 6).

The distal spicule tip was short and pointed; the length of the free distal end was longer than the spicule width $(0.013$ versus 0.011$)$. Following Fagerholm's approach (1989), the measurements of the distal end of the spicule $(n=1)$ in $\mu$ m were: A-B: 12.6 ; A-C: 16.3 ; A-D: 35.6; Dist $B^{*}-B^{\circ}$ : 12.6; E-F: 8.2; E-H: 23.7; E-I: 30.4; and F-G: 11.1 (Figure 7)

Measurements on female specimen $(\mathrm{n}=1)$ : body length 31.85 ; maximum body width 0.86 ; distance from anterior end to nerve ring and deirids 0.45 and 0.54 respectively; esophagus length 3.8 ; intestinal caecum length 2.57; ventricular appendix length 1.1; vulva in anterior half of the body and tail length 0.65 (Figure 8).

The information provided by Mozgovoi (1953) coincides with that of Cram (1927) and so it was not included in Table 1.

The morphology and dimensions of our specimens were concordant with previous reports (CRAM, 1927; MOZGOVOI, 1953; MACKO, 1961; HARTWICH, 1964). Although the complexity of the lips was best discerned by Hartwich (1964), the ultrastructural observations made in the present report showed two small auricles and that the interlabia was one third of the lip height and triangle-shaped, in conformity with this author's findings. Fagerholm (1989) considered that the length of the spicules, morphology of the distal end of the spicule and number and distribution of caudal papillae in the males were other good taxonomic criteria. The number and distribution pattern of the caudal papillae agree with those of previous descriptions (CRAM, 1927; HARTWICH, 1964), but the details of the distal end of the spicules at ultrastructural level are described for the first time in the present paper. Macko (1961) and Cram (1927) reported 10 pairs of precloacal papillae, but Hartwich (1964) reported 29-35 pairs of precloacal papillae. Previous authors reported a wide range of intraspecies variation with regard to the number of precloacal papillae in anisakids: 60-81 pairs in C. osculatum (FAGERHOLM, 1989), 23 - 49 in C. ogmorhini (FAGERHOLM; GIBSON, 1987) and $44-61$ in Terranova galeocerdonis (TANZOLA; SARDELLA, 2006). For this reason, we can accept that the differences observed in relation to Hartwich's specimens may correspond to such intraspecies variation.

In Argentina, several species of Contracaecum have been reported parasitizing birds from freshwater, brackish water and marine ecosystems. Contracaecum microcephalum (Rudolphi, 1809) has been described parasitizing the Ardeidae species Ardea cocoi Linnaeus, Egretta alba (Gmelin, 1789), Nycticorax nycticorax (Gmelin, 1789) and Casmerodius albus egretta (Lineé, 1766) in Buenos Aires province and C. multipapillatum has been described parasitizing E. alba (BOERO; LED, 1971; NAVONE et al., 2000). Contracaecum travassosi (Gutierrez, 1943) has been described in Phalacrocorax atriceps (= P. albiventer) (Lesson, 1831). Garbin et al. (2007) redescribed C. pelagicum (Johnston and Mawson, 1942) in Thalassarche melanophris Temminck and Spheniscus magellanicus Foster. In the latter host, Pazos et al. (2003) found C. spheniscus Boero and Led (1970) and C. chubutensis in P. atriceps King (GARBIN et al., 2008). The last three species came from Chubut province in Patagonia. This is the first record of C. ovale in $R$. rolland in Argentina, and it confirms the marked specificity of this species for podicipediform birds.

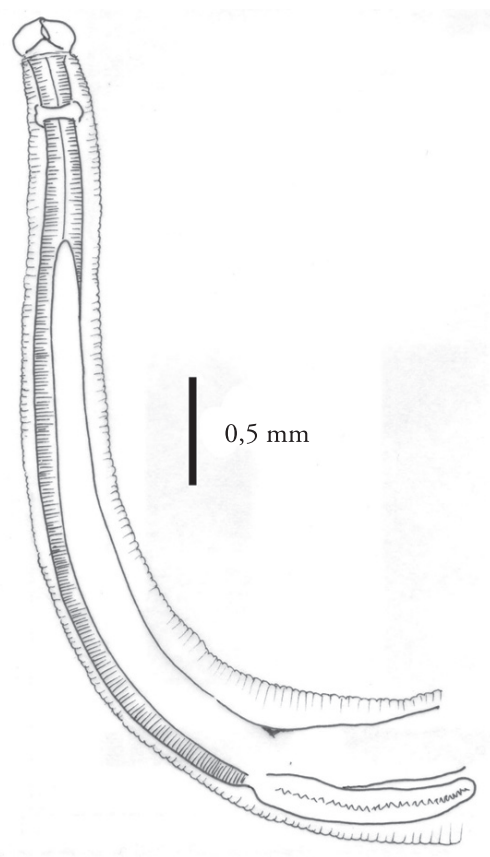

Figure 1. Contracaecum ovale (Linstow, 1907) from Rollandia rolland in Argentina: anterior end, esophagus, intestinal caecum and ventricular appendix. 

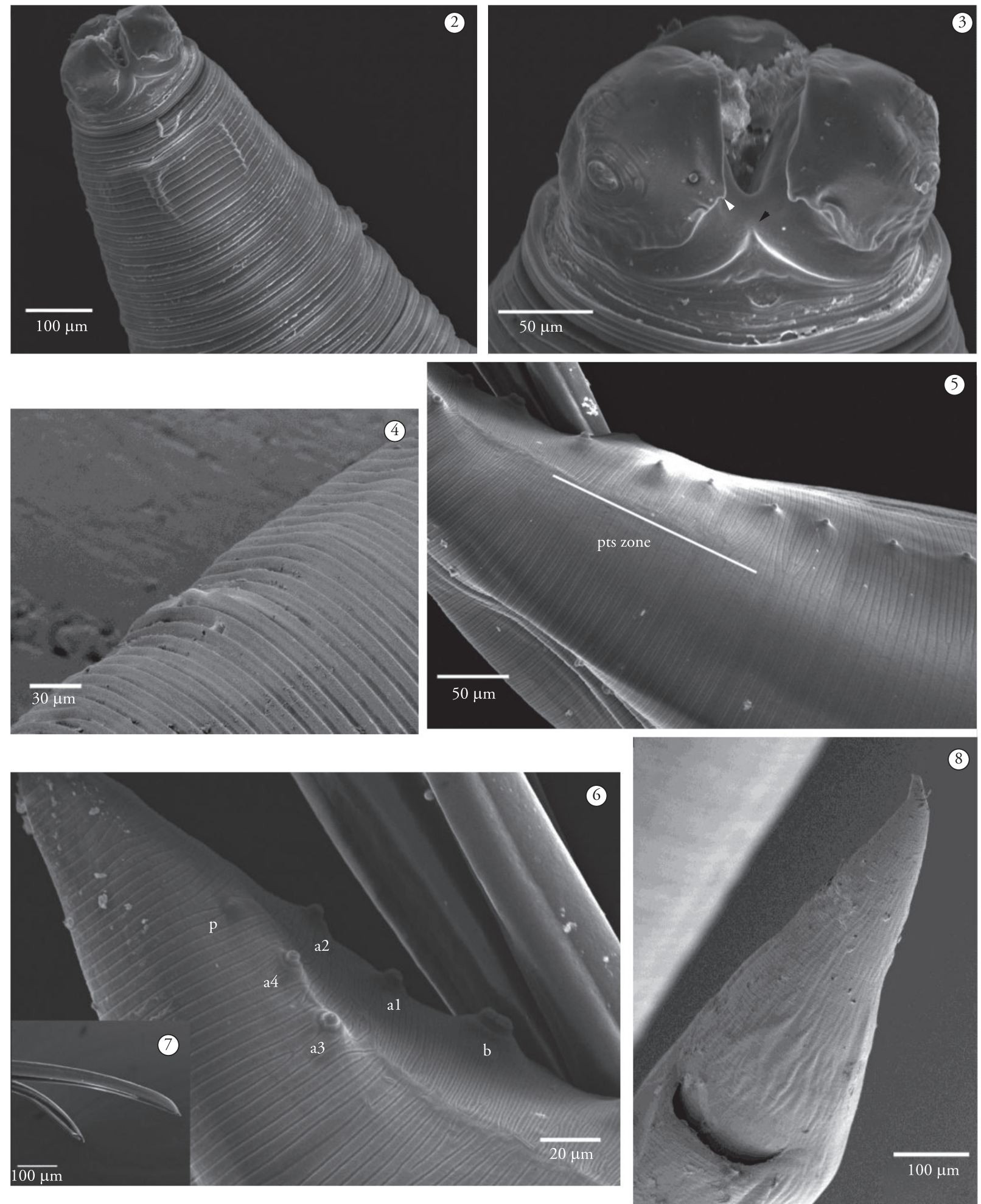

Figure 2-8. Contracaecum ovale from $R$. rolland in Argentina. 2) Anterior end, lateroventral view; 3) Anterior end details: lips, interlabia (black arrow), excretory pore, amphid, lip auricular tip (white arrow); 4) Details of a deirid; 5) Proximal precloacal papillae; 6) Male caudal extremity, detail of the postcloacal papillae: a1-a2 subventral papillae, a3-a4 sublateral papillae, p phasmid, b double paracloacal; 7) Distal spicule tip; 8) Posterior female extremity. 
Table 1. Comparative morphometric data (in $\mathrm{mm}$ ) on Contracaecum ovale.

\begin{tabular}{|c|c|c|c|c|}
\hline References & Macko (1961) & Cram (1927) & Hartwich (1964) & Present study \\
\hline Host & Podiceps griseigena & Podiceps cristatus & $\begin{array}{l}\text { Podiceps } \\
\text { cristatus }\end{array}$ & Rollandia rolland \\
\hline Localities & Czech Republic & Germany & Brazil & $\begin{array}{c}\text { Buenos Aires province, } \\
\text { Argentina }\end{array}$ \\
\hline Male & & & $\mathrm{n}=6$ & $\mathrm{n}=3$ \\
\hline Body length & 29 & 29 & $16.10-32.8$ & $18.5(18-19)$ \\
\hline Deirids (dae) & - & - & - & 0.69 \\
\hline Esophagus length & 4.83 & & $2.46-5.07$ & 3.4 \\
\hline Intestinal caecum length & 4.05 & - & $1.7-4.1$ & 2.7 \\
\hline Ventricular length & - & - & & 0.16 \\
\hline Ventricular appendix length & 2.89 & & $1.33-2.59$ & 0.70 \\
\hline $\mathrm{PrPP}$ & 10 & 10 & $25-35$ & $12-16$ \\
\hline $\mathrm{BL} / \mathrm{MBW}$ & - & - & $47.7(42.6-55.1)$ & 26.81 \\
\hline $\mathrm{BL} / \mathrm{EL}$ & - & - & $6.27(5-7.86)$ & 5.44 \\
\hline $\mathrm{BL} / \mathrm{TL}$ & - & - & $104.6(74.6-160)$ & 28.9 \\
\hline EL/ICL & - & - & $1.35(1.24-1.45)$ & 1.25 \\
\hline EL/VAL & - & - & $2.04(1.74-2.8)$ & 4.85 \\
\hline $\mathrm{BL} / \mathrm{SL}$ & - & - & $9.83(8.21-11.16)$ & 6.34 \\
\hline Female & - & & $\mathrm{n}=6$ & $\mathrm{n}=1$ \\
\hline Body length & 14 & 44 & $17.35-50.2$ & 31.85 \\
\hline Maximum body width & 1.38 & 1.38 & $0.32-0.96$ & 0.86 \\
\hline Egg width & 0.057 & 0.057 & $0.05-0.053$ & 0.04 \\
\hline Tail length & - & 0.23 & 0.35-0.69 & 0.65 \\
\hline BL/MBW & - & - & $45(36.5-52.8)$ & 37.03 \\
\hline $\mathrm{BL} / \mathrm{EL}$ & - & - & $7.6(5.82-9.11)$ & 8.38 \\
\hline $\mathrm{BL} / \mathrm{TL}$ & - & - & $63.4(46-91.2)$ & 49 \\
\hline EL/ICL & - & - & $1.43(1.35-1.5)$ & 1.47 \\
\hline EL/VAL & - & - & $2.13(1.61-3.28)$ & 3.75 \\
\hline
\end{tabular}

dae = distance from anterior end; PrPP: precloacal papilla pairs; BL/MBW: body length/maximum body width ratio; BL/EL: body length/esophagus length ratio;

BL/TL: body length/tail length ratio; EL/ICL: esophagus length/intestinal caecum length ratio; EL/VAL: esophagus length/ventricular appendix length ratio; BL/

SL: body length/spicule length ratio.

\section{References}

Baylis J. Further records of Parasitic worm from British Vertebrates. Ann Mag Nat Hist 1939; 4: 473-498. http://dx.doi. org/10.1080/00222933908527013

Boero JJ, Led JE. El parasitismo de la fauna autoctona. V. Los parasitos de las aves argentinas. Analect Vet 1971; 3(1-3): 91-103.

Boero JJ, Led JE, Brandetti E. Algunos parásitos de la avifauna argentina. Analect Vet 1972, 4(1): 17-25.
Cram E. Birds parasites of nematode suborders Strongylata, Ascaridata and Spirurata. Bull US Natl Mu 1927; 140: 155-156.

Fagerholm HP. Intra-specific variability of the morphology in a single population of the seal parasite Contracaecum osculatum (Rudolphi) (Nematoda, Ascaridoidea), with a redescription of the species. Zool Scr 1989; 18(1): 33-41. http://dx.doi.org/10.1111/j.1463-6409.1989. tb00121.x

Fagerholm HP. Systematic implications of male caudal morphology in ascaridoid nematode parasites. Syst Parasitol 1991; 19(3): 215-229. http:// dx.doi.org/10.1007/BF00011888 
Fagerholm HP, Gibson DI. A redescription of the pinniped parasite Contracaecum ogmorhini (Nematoda, Ascaridoidea), with an assessment of its antiboreal circumpolar distribution. Zool Scr 1987; 16(1): 19-24. http://dx.doi.org/10.1111/j.1463-6409.1987.tb00047.x

Fjeldsa J. The Grebes: Podicipedidae. New York: Oxford University Press; 2004.

Garbin LE, Navone GT, Diaz JI, Cremonte F. Further study of Contracaecum pelagicum (Nematoda: Anisakidae) in Spheniscus magellanicus (Aves: Spheniscidae) from Argentinean coasts. J Parasitol 2007; 93(1): 143-150. PMid:17436954. http://dx.doi.org/10.1645/ GE-875R1.1

Garbin LE, Diaz JI, Cremonte F, Navone GT. A new anisakid species parasitizing the imperial cormorant Phalacrocorax atriceps from the north Patagonian coast, Argentina. J Parasitol 2008; 94(4): 852-859. PMid:18837571. http://dx.doi.org/10.1645/GE-1369.1

Hartwich G. Die Typen Parasitischer Nematoden in der Helminthen-Sammlung des Zoologischen Museums in Berlin. I. Ascaridoidea. Mitt Zool Mus 1964; 40: 1-53.

Macko JK. Niektoré pozorovania o premenlivosti druhu Contracaecum (Contracaecum) nebli Karokhin, 1949. Biol Brat 1961; 16(10): 740-748.
Mozgovoi AA. Ascaridata of animals and man and the diseases caused by them. Moscow: Akademiya Nauk. Osnovy Nematodologii; 1953.

Navone GT, Etchegoin JA, Cremonte F. Contracaecum multipapillatum (Nematoda: Anisakidae) from Egretta alba (Aves: Ardeidae) and comments on the species of this genus in Argentina. J Parasitol 2000; 86(4): 807-810. PMid:10958460.

Pazos GE, Laurenti S, Diaz JE. Helmintofauna del pingüino de Magallanes (Spheniscus magellanicus) en Península Valdés, Provincia del Chubut. Resultados Preliminares. Hist Nat 2003; 2(10): 85-94.

Stock TM, Holmes JC. Host specificity and exchange of intestinal helminths among four species of grebes (Podicipedidae). Can J Zool 1987; 65(3): 669-676. http://dx.doi.org/10.1139/z87-104

Storer RW. Observations on Rolland's Grebe. El Hornero 1967; 10: 339-350.

Tanzola RD, Sardella NH. Terranova galeocerdonis (Thwaite, 1927) (Nematoda: Anisakidae) from Carcharias taurus (Chondrichthyes: Odontaspididae) off Argentina, with comments on some related species. Syst Parasitol 2006; 64(1): 27-36. PMid:16612662. http://dx.doi. org/10.1007/s11230-005-9015-5 